\title{
WIEDZA O ŚWIECIE A CZYTANIE ZE ZROZUMIENIEM W JĘZYKU HISZPAŃSKIM JAKO OBCYM
}

\begin{abstract}
Słowa kluczowe: czytanie w języku obcym, rozumienie tekstów literackich, wiedza o świecie, hiszpański jako język obcy

Streszczenie. Celem artykułu było przeanalizowanie znaczenia rozumienia i posiadanej wiedzy w czytaniu tekstów literackich w języku hiszpańskim jako obcym. Przeprowadzono badanie dotyczące rozumienia i wnioskowania w rozumieniu nacechowanych kulturowo elementów tekstowych we fragmentach trzech tekstów literackich. Badani byli studenci pierwszego i drugiego roku studiów języka i literatury hiszpańskiej. Wnioski wskazują, że odpowiednie rozumienie tekstu zależy od wiedzy językowej i kulturowej oraz że znajomość kodu językowego nie kompensuje braku wiedzy o świecie.
\end{abstract}

\section{CZYTANIE ZE ZROZUMIENIEM}

Nowoczesne konstruktywistyczne podejście do czytania opisuje je jako proces kształtowania się znaczenia (Grabe, Stoller 2002; Grabe 2009; Čudina-Obradović 2014). Akcentuje się przy tym interaktywność procesu, w którym czytelnik, zaczynając od własnej wiedzy językowej i ogólnej oraz czytanego tekstu, interpretuje znaczenia. Uznaje się, że rola czytelnika jest aktywna, ponieważ tekst odbiera i interpretuje (López Alonso, Serrè 2001). Akcentuje się również przy tym odpowiednie rozumienie informacji, co zazwyczaj konceptualizuje się w kształtowaniu interpretacji tekstu (Van Dijk, Kintsch 1983; Kintsch 2004). Innymi słowy, czytelnik kształtuje rozumienie na trzech poziomach. Oprócz poziomu powierzchniowego, który obejmuje dekodowanie podstawowych formuł tekstowych i bardzo szybko przestaje być zauważany przez czytelnika, samo Zagreb.

*acavar@ffzg.hr; Instytut Kroatystyki, Uniwersytet w Zagrzebiu, Ivana Lučića 3, 10000 
rozumienie kształtuje się na poziomie bazy tekstowej (ang. text base) i modelu sytuacyjnego (ang. situational model, event model). Poziom bazy tekstowej zawiera połączone w sieć ważniejsze ujawniane eksplicytnie informacje, natomiast poziom modelu sytuacyjnego bardziej opiera się na aktywizacji wiedzy ogólnej czytelnika oraz reprezentuje interpretację tekstu przez czytelnika.

Rozumienie tekstu oznacza przede wszystkim rozpoznawanie ważnych informacji w tekście i relacji między nimi, w dużej części uwarunkowane jest bowiem wnioskowaniem. Teksty mianowicie nie są zawsze w pełni eksplicytne, więc „łuki semantyczne, które wynikają z tych pustych miejsc muszą być dopełnione wnioskami opierającymi się na posiadanej wiedzy" (Koda 2010, s. 6). Przy tym wnioskowanie na poziomie bazy tekstowej uważa się za mniej wymagające niż kształtowanie wniosków na poziomie modelu sytuacyjnego. Wnioskowanie na poziomie bazy uwzględnia na przykład pojawianie się relacji anaforycznych w tekście, podczas gdy wnioskowanie na poziomie modelu sytuacyjnego jest bardziej skomplikowane i opiera się na wiedzy czytelnika umożliwiającej zwracanie uwagi na te dane, które w tekście nie są eksplicytnie wyrażone, a są niezbędne do zrozumienia. Wnioskowanie w rozumieniu jest zatem ściśle związane ze standardem spójności, który jest ustanawiany przez czytelnika, a w literaturze opisuje się go jako poziom tolerancji w stosunku do ewentualnych rozbieżności tekstu lub nieścisłości $\mathrm{w}$ interpretacji tekstu oraz zgodności wiedzy czytelnika z przeczytanym tekstem (Čudina-Obradović 2014). Standard spójności decyduje, w jakiej mierze czytelnicy naprawdę rozumieją tekst, kształtują wnioski i monitorują własne rozumienie tekstu (Perffeti i in. 2009).

\subsection{WIEDZA I ROZUMIENIE W CZYTANIU}

Rola posiadanej wiedzy w literaturze dotyczącej czytania badana była przede wszystkim w ramach teorii schematów ${ }^{1}$. Alderson (2000, s. 33) schematy te opisuje jako „wzajemnie związane struktury mentalne, które reprezentują wiedzę czytelnika". Wprowadzenie pojęcia schemat w literaturze przypisuje się Bartlettowi, który pierwszy opisał tendencję czytelnika do asymilacji kulturowo nacechowanych elementów tekstowych uwarunkowanych posiadaną wiedzą. W latach osiemdziesiątych XX wieku za pomocą teorii schematów zaczyna się opisywać semantyczne przetwarzanie tekstów podczas czytania. Od tej pory różne, najczęściej międzykulturowe badania, podkreślały rolę posiadanej, a nawet kulturowo uwarunkowanej wiedzy w rozumieniu. Tę kulturowo uwarunkowaną wiedzę

\footnotetext{
${ }^{1}$ Wiedza w literaturze dotyczącej rozumienia definiowana jest czasami także jako rama, plan lub scenariusz, ale jak twierdzi Alderson (2000), podobieństwa między różnymi konceptualizacjami posiadanej wiedzy większe są od ich różnic.
} 
w nauce definiuje się jako ,wiedzę o tym, jak świat funkcjonuje” (Alderson 2000, s. 44) - zazwyczaj jest ona bliska wzorcom kulturowym czytelnika. Okazało się, że czytelnicy lepiej rozumieją i pamiętają te teksty, które powstawały w bliskich im kulturowo kręgach oraz że w czytaniu tekstów z innego kulturowego kontekstu informacje przystosowują i interpretują zgodnie $\mathrm{z}$ schematami przyjętymi w bardziej znanej sobie kulturze.

\subsection{CZYTANIE ZE ZROZUMIENIEM W JĘZYKU OBCYM}

Konstruktywistycznie opisuje się również proces dekodowania tekstu w języku obcym, tylko że w takiej formie, jak uznają López Alonso i Serrè (2001), do tekstu podchodzi się za pomocą języka obcego, jest on więc zawsze pośredni. Na rozumienie tekstu, który jest napisany w języku dla czytenika obcym, w którym ponadto nie posiada on wystarczającej kompetencji, wpływają różne elementy. Jako najważniejsze w złożonych procesach kształtowania rozumienia López Alonso i Serrè (2001, s. 5) wskazują posiadaną wiedzę czytelnika, tekst i język, w którym tekst jest napisany oraz procesy czytelnicze. Wpływ wymienionych komponentów oraz poziom ich łączliwości i zgodności podczas czytania warunkuje rożnice w czytaniu i rozumieniu w języku obcym²

Badania czytania w języku obcym objaśniają wiedzę przeważnie za pomocą schematów i dzielą ją na wiedzę o języku obejmującą tę o kodzie językowym, schematy formalne, czyli wiedzę o dyskursie i cechach formalnych określonego gatunku tekstu oraz na schematy treści związane z wiedzą o treści tekstu (Carrell 1983). Trudności w rozumieniu tekstu wyjaśniają niezbywaniem i/lub nieaktywnością czytelnika do odpowiednego rozumienia schematów, od językowych do treściowych.

W badaniach o czytaniu w języku obcym zwykle sprawdzano wpływ wiedzy językowej na rozumienie tekstu. Jednak w ostatnich dwudziestu latach weryfikowano także wpływ wiedzy kulturowej. Zaczynając od wyników badań, które pokazały, że wiedza o języku i dyskursie, mimo że stanowi niezbędny warunek, nie może zastąpić wiedzy o treści w kształtowaniu znaczenia (Britton, Gulgoz 1994; za: Kintsch 2004), o czytaniu w języku obcym częściej mówi się jako o formie czytania międzykulturowego (Grosman 2004). Czytanie w pozycji międzykulturowej Grosman definuje jako czytanie tekstów dalszych od bliskiego kulturowo otoczenia czytelnika. Innymi słowy, o czytaniu w pozycji międzykulturowej mówi się zawsze, kiedy z tekstem spotykają się czytelnicy „,kulturowo uspołecznieni w jakiejś innej kulturze“" (Grosman 2004, s. 42), niezależnie od tego, czy

${ }^{2}$ Szczegóły o różnicach w czytaniu w języku ojczystym i obcym zob. np. Grabe i Stoller 2002, s. $40-63$. 
tekst przekazuje się w oryginale lub w znanym czytelnikowi kodzie językowym. Chociaż oryginalnie tworzony dla metodyki i glottodydaktyki, taki podział korzystny jest także jako jeden z punktów wyjścia w badaniach dotyczących czytania, ponieważ, po pierwsze, zaczyna się od procesów czytelniczych i roli posiadanej wiedzy w rozumieniu, a po drugie, umożliwia rozpoznanie takich elementów tekstu, których rozumienie w kształtowaniu znaczenia mogłoby być utrudnione. Wychodząc od czytania tekstów literackich w języku obcym jako jednej z form czytania międzykulturowego, w tym artykule mówi się o niektórych aspektach wiedzy kulturowej w kształtowaniu interpretacji tekstu.

\section{WIEDZA O ŚWIECIE I ROZUMIENIE TEKSTÓW PISANYCH - PRZEGLĄD WAŻNIEJSZYCH BADAŃ}

Wpływ posiadanej wiedzy na rozumienie badano intensywnie, zwłaszcza w literaturze o czytaniu ze zrozumieniem w języku obcym. Niżej zostaną opisane najważniejsze badania, które zajmowały się rolą wiedzy o świecie i bliskości tematycznej w czytaniu ${ }^{3}$.

Pierwsze badania porównawcze przeprowadził Frederic C. Bartlett (1932). W latach trzydziestych XX wieku przeprowadził kilka serii doświadczeń dotyczących tego, jak uczestnicy przypominają sobie przeczytane teksty, dokładnie legendy Indian amerykańskich. Skonstatował, że przypominając sobie historię tworzoną w nieznanej im tradycji kulturowej, korzystają z własnej wiedzy jako swego rodzaju filtra kulturowego. Innymi słowy zauważył, że w rozumieniu nieznanych szczegółów istnieje tendencja do korzystania z wiedzy już znanej lub przynajmniej bliższej. Najwięcej takich badań przeprowadzano w latach osiemdziesiątych XX wieku, kiedy teorią schematów były wyjaśniane różne aspekty rozumienia. Jednym z nich, które zazwyczaj bierze się pod uwagę jako potwierdzenie teorii schematów, jest badanie Steffenson i in. (1979; za: Anderson 2004). Badanie obejmowało dwie różne grupy etniczne, Amerykanów i Hindusów. Tematy tekstów, za pomocą których badano rozumienie oraz informacje, które respondenci zapamiętali po czytaniu, były związane z ceremonią ślubną jako pewnego rodzaju specyfiką kulturową w obydwu grupach społecznych. Założeniem badacza było to, że każdy dorosły członek grupy językowej i kulturowej posiada dobrze rozbudowany schemat ceremonii ślubnej we własnym otoczeniu kulturowym. Wyniki pokazały, że obydwie grupy szybciej czytały, lepiej zrozumiały i zapamiętały więcej informacji z tekstów, które były im doświadczeniowo bliższe. Wyjaśnia się to tym, że aktywacja znanego schematu przyspiesza proces czytania i ułatwia

${ }^{3}$ Dokładny przegląd i opis badań na temat wpływu posiadanej wiedzy na czytanie można znaleźć w: Davoudi i Ramezani (2014). 
zrozumienie. Opisane badanie potwierdziło, że czytelnicy lepiej rozumieją i pamiętają te teksty, które są tworzone w bliskim im kontekście kulturowym oraz że w czytaniu tekstów dalszych kulturowo, informacje są przystosowywane i wyjaśniane zgodnie ze schematami przyjętymi w znanej kulturze.

Podobne wyniki uzyskano w kolejnych badaniach, które przeprowadzono wśród osób uczących się języków obcych, zwłaszcza angielskiego. Na przykład P. Carrell (1981; za: Carrell, Eisterhold 1983) stwierdził, że bliskość kulturowa tekstu czytanego wpływa na jego zrozumienie. Badani, których językami ojczystymi były japoński i chiński, po angielsku czytali legendy thumaczone z japońskiego, chińskiego, francuskiego oraz legendy Indian amerykańskich. Wyniki znowu podkreśliły znaczenie wiedzy kulturowej, ponieważ okazało się, że rozumienie jest uwarunkowane bliskością, która znów słabnie wraz ze wzrostem dystansu kulturowego. Okazało się też, że dla badanych mniej zrozumiałe były teksty uporządkowane według struktury innej od struktury tekstów własnego kręgu kulturowego.

Ciekawe są także wyniki badań Winfield i Barnes-Felfeli (1983; za: Al-Issa 2006), którzy badali rozumienie tekstu czytanego wśród osób, które uczyły się angielskiego jako języka obcego na poziomie średnio zaawansowanym. Dla jednej połowy badanych językiem ojczystym był hiszpański, a druga połowa była językowo różnorodna (arabski, grecki, hebrajski itp.). Badani czytali dwa teksty - tłumaczenie Don Kichota i tekst o japońskim teatrze nō. Podczas gdy między badanymi, których językiem ojczystym nie był hiszpański, nie było wielkich różnic w rozumieniu obydwu tekstów, badani z hiszpańskiego obszaru językowego widocznie lepsze wyniki osiągnęli, czytając tłumaczenie Don Kichota. Różnice w rozumieniu wyjaśnione są wiedzą kulturową ułatwiającą hiszpańskojęzycznym badanym rozumienie tekstu, będącego ważnym komponentem ich kontekstu kulturowego.

\section{BADANIE}

Badanie kwantytatywne zostało przeprowadzone w marcu 2016 r. wśród studentów pierwszego i drugiego roku Studiów Licencjackich Języka i Literatury Hiszpańskiej na Wydziale Humanistycznym Uniwersytetu w Zagrzebiu. W badaniu udział wzięło ogółem 41 studentów. Wśród nich 39\% ( $\mathrm{N}=16)$ było na pierwszym, a $61 \%(\mathrm{~N}=25)$ na drugim roku studiów. Dla wszystkich badanych język hiszpański jest językiem obcym, a tylko dla jednego z nich język chorwacki nie jest językiem ojczystym. Mając na uwadze, że badani są studenci pierwszego i drugiego roku studiów języka i literatury hiszpańskiej, zakładana jest odpowiednio rozwinięta kompetencja czytania w języku ojczystym oraz kompentencja 
komunikacyjna w języku obcym według Europejskiego Systemu Opisu Kształcenia Językowego (2003). Potwierdziła to większość odpowiedzi w ankiecie (94\%, $\mathrm{N}=36$ ), w której studenci musieli ewaluować własną kompetencję komunikacyjną w języku hiszpańskim.

Celem badania było przeanalizowanie wpływu niektórych aspektów wiedzy kulturowej w rozumieniu tekstów literackich podczas czytania w języku hiszpańskim. Żeby odpowiedzieć na pytanie badawcze, sformułowano następujące hipotezy:

H1 Rozumienie tekstu uwarunkowane jest posiadaniem odpowiednej wiedzy kulturowej, której w tekście nie można zastąpić wiedzą o leksyce i strukturach językowych. Czytelnicy, którzy nie posiadają odpowiednej wiedzy kulturowej nie mogą dojść do odpowiednich wniosków, co wpływa na spójność ich interpretacji tekstu.

H2 W miejscach w tekście, w których wymaga się od czytelnika wniosków opartych na wiedzy kulturowej, zwłaszcza socjokulturowej, częściej pojawiają się zniekształcenia interpretacji tekstu.

\subsection{INSTRUMENTARIUM}

Żeby odpowiedzieć na pytania, przygotowane zostały również odpowiednie materiały. Ankieta składała się z trzech fragmentów tekstów literackich (fragmentu Usted tiene ojos de mujer fatal (1932) E. J. Ponceli, fragmentu Vistas a la luna (1999) G. Morales i fragmentu Don Kichota M. de Cervantesa) ${ }^{4}$, kwestionariusza, za pomocą którego sprawdzono rozumienie oraz zadania, w którym studenci musieli na skali Likerta (od bardzo źle do bardzo dobrze) ocenić zrozumienie przeczytanych fragmentów. Ze względu na to, że fragmenty były wzięte ze znanych dzieł, w zdaniu wstępnym umieszczone zostały dane, które są niezbędne do zrozumienia samych fragmentów. W jednym miejscu język trzeciego fragmentu był unowocześniony, dokładnie archaizm maese został zastąpiony bardziej znanym wyrazem. Przy selekcji tekstów badawczych pod uwagę wzięto spójność, długość i liczbę kulturowo nacechowanych elementów. Długość tekstów w ankiecie to kolejno 355, 252 i 336 słów.

Aby sprawdzić rozumienie tekstu, sformułowano w sumie 17 pytań (6 dla pierwszego i trzeciego, a 5 dla drugiego fragmentu). Pytania te były przede wszystkim pytaniami otwartymi - podsumowaniem akapitów, wyjaśnieniem re-

${ }^{4}$ Teksty badawcze wzięte są z następujących źródeł: Poncela E., 1995, Usted tiene ojos de mujer fatal, Madrid, s. 99-100; Morales G., 2000, Vistas a la luna [online], www.remiendoteatro. com, [1.2.2016]; Cervantes M., 1999, Don Quijote, Alicante [online], http://www.cervantesvirtual. com/obra-visor-din/el-ingenioso-hidalgo-don-quijote-de-la-mancha-6/html/05f86699-4b53-4d9b -8ab8-b40ab63fb0b3_2.html\#I_10_, [10.2.2016]. 
lacji między bohaterami i motywami ich działań lub w kontekście danego akapitu wyjaśnieniem oznaczonych fragmentów. Trzy pytania były jednak pytaniami zamkniętymi - badani musieli zaznaczyć tylko jedną prawidłową odpowiedź spośród kilku proponowanych. Wszystkie pytania były nakierowane na rozumienie tekstu. Po każdym tekście i odpowiedziach na pytania, badani ewaluowali własne rozumienie.

\subsection{POSTEPOWANIE BADAWCZE}

Anonimowe badanie przeprowadzono na Wydziale Humanistycznym w Zagrzebiu w 2016 r. Badani byli podzieleni na trzy grupy. Wypełnianie ankiet w każdej z nich trwało 40 minut. Studenci czytali teksty po hiszpańsku, a odpowiadali po chorwacku, żeby uniknąć wpływu niedostatecznej wiedzy o kodzie języka hiszpańskiego na wyniki. Także podczas czytania musieli zaznaczyć nieznane słowa, aby sprawdzić adekwatność tekstów do poziomu ich biegłości językowej. Jedynym dziełem, które znali, był Don Kichot.

\subsection{WYNIKI}

Dane zostały przetworzone w programie statystycznym SPSS, aby rzetelnie odpowiedzieć na pytanie badawcze. Wyniki są opisane podstawowymi deskryptywnymi wskaźnikami. Ze względu na to, że grupa badawcza byłą niewielka, wyniki zostały wyrażone w procentach. Jeżeli było to konieczne, zostały uzupełnione liczbą badanych $(\mathrm{N})$.

Podczas czytania tekstów badani musieli zaznaczyć wszystkie nieznane słowa. Celem było, przy uwzględnieniu progu leksyki niezbędnej do zdekodowania tekstu, sprawdzenie adekwatności tekstów względem poziomu grupy (możliwość samodzielnego czytanie ze zrozumieniem). Niektóre badania czytania w języku obcym próbowały ustalić, czy istnieje próg wiedzy językowej, odpowiedniego słownictwa, które reprezentuje minimum wiedzy potrzebnej do zrozumienia danego tekstu. Ewaluacja zakresu potrzebnej wiedzy leksykalnej waha się pomiędzy 85 a nawet $99 \%$ w czytaniu niektórych gatunków (Nation 1985; za: Waring, Nation 1997). W tym artykule pierwszeństwo daje się progowi leksykalnemu stworzonemu przez Nagya i Scotta (2004), oceniającemu, że niezbędnym warunkiem do kształtowania odpowiednej bazy tekstowej jest leksykon mentalny obejmujący przynajmniej podstawowe znaczenia (90 do 95\% słów w tekście). Procent znanych słów w tekstach badawczych wynosił kolejno 98,5\%, 98,2\% i 98\%. 
Ze względu na to, że rozumienie tekstu często sprawdza się za pomocą streszczeń, rozumienie pierwszych dwóch akapitów było sprawdzane właśnie w ten sposób. W pierwszym teście $95 \%$ badanych $(\mathrm{N}=39)$ poprawnie odpowiedziało na pytanie, podczas gdy drugi tekst skutecznie streściło tylko $22 \%(\mathrm{~N}=9)$. Po czytaniu trzeciego tekstu nie zastosowano streszczenia, bo przypuszczano, że większość badanych przynajmniej częściowo zna treść Don Kichota.

Rozumienie sprawdzano także pytaniami otwartymi. W tabeli 1. równolegle pokazany jest procent poprawnych odpowiedzi z niektórymi podstawowymi deskryptywnymi wskaźnikami.

Tabela 1. Liczba nieznanych słów, procent poprawnych odpowiedzi w pytaniach o rozumienie i samoocena rozumienia tekstu $(\mathrm{N}=41)$

\begin{tabular}{|c|c|c|c|c|c|c|c|}
\hline & & \multicolumn{2}{|c|}{ Tekst 1} & \multicolumn{2}{|c|}{ Tekst 2} & \multicolumn{2}{|c|}{ Tekst 3} \\
\hline & $\begin{array}{l}\text { Liczba nieznanych } \\
\text { slów (C) }\end{array}$ & \multicolumn{2}{|c|}{1,12} & \multicolumn{2}{|c|}{1,58} & \multicolumn{2}{|c|}{1,48} \\
\hline & $\begin{array}{l}\text { Procent znanych } \\
\text { slów }\end{array}$ & \multicolumn{2}{|c|}{98,5} & \multicolumn{2}{|c|}{98,2} & \multicolumn{2}{|c|}{98} \\
\hline & & $\%$ & $\mathbf{N}$ & $\%$ & $\mathbf{N}$ & $\%$ & $\mathbf{N}$ \\
\hline \multirow{7}{*}{$\begin{array}{l}\text { Procent popraw- } \\
\text { nych odpowiedzi } \\
\text { w pytaniach } \\
\text { o rozumienie }\end{array}$} & Żaden & 0 & 0 & 2,4 & 1 & 2,4 & 1 \\
\hline & Jeden & 0 & 0 & 26,8 & 11 & 4,9 & 2 \\
\hline & Dwa & 4,9 & 2 & 24,4 & 10 & 14,6 & 6 \\
\hline & Trzy & 34,1 & 14 & 34,1 & 14 & 17,1 & 7 \\
\hline & Cztery & 36,6 & 15 & 9,8 & 4 & 22 & 9 \\
\hline & Pięć & 22 & 9 & 2,4 & 1 & 17,1 & 7 \\
\hline & Sześć & 2,4 & 1 & 1 & 1 & 19,5 & 8 \\
\hline \multicolumn{2}{|c|}{$\begin{array}{c}\text { Najczęściej wybrana samoocena } \\
\text { rozumienia }\end{array}$} & \multicolumn{2}{|c|}{$3(51 \%)$} & \multicolumn{2}{|c|}{$3(44 \%)$} & \multicolumn{2}{|c|}{$3(49 \%)$} \\
\hline
\end{tabular}

Źródło: oprac. własne

Wyniki pokazują, że badani najgorzej zrozumieli drugi fragment. Interesujące jest, że w rozumieniu pierwszego i trzeciego fragmentu nie ma większych różnic, co - mając na uwadze, że trzeci fragment pochodzi z dzieła Cervantesa - nie jest spodziewanym wynikiem. Rozumienie starszych tekstów literackich, z pozycji współczesnej recepcji, zazwyczaj uważane jest za bardziej wymagające od rozumienia tekstów aktualnych. To zjawisko często łączy się ze stratyfikacją temporalną języka oraz z mniej znanymi cechami poetyckimi starszych tekstów. Wyniki pokazują również, że samooceny rozumienia badanych są stosunkowo podobne i w mniejszej mierze odzwierciedlają różnice w kształtowaniu interpretacji tekstu, na co wskazują procenty poprawnych odpowiedzi po czytaniu oraz wyniki z zadania ze streszczeniem.

Ze względu na to, że celem badania było przeanalizowanie roli wiedzy kulturowej w procesie rozumienia tekstów pisanych, materiały badawcze zostały wybrane także pod względem liczby kulturowo nacechowanych elementów tekstowych. 
We fragmentach poddanych badaniu obejmują one szeroki wachlarz odniesień, opisanych w Plan Curricular del Instituto Cervantes (2006), podstawowym dokumencie służącym do tworzenia programów dydaktycznych do nauki języka hiszpańskiego jako obcego, który zawiera inwentarz kulturalny pod tytułem Referentes culturales i Saberes y comportamientos culturales (Molina 2006) ${ }^{5}$. Należy powiedzieć, że teksty nie zawsze związane są z kulturą obszaru badanego języka (por. biblizmy czy powszechnie znaną historię o Sinobrodym). Także niektóre elementy, które wiążą się z kulturą Hiszpanii, dzisiaj można - przynajmniej w kontekście europejskim - uważać za uniwersalne (jak Don Juan i Don Kichot). Oprócz tego, rozumienie tekstów wymagało rozpoznania niektórych specyficznych elementów, które można uważać za swoiste dla przestrzeni hiszpańskiej, takich jak uzus w funkcjonowaniu grup społecznych, literatura oralna charakterystyczna dla dyskursu dziecięcego lub aluzje do kultury popularnej i dyskursu reklamowego. Ze względu na to, że wymienione zjawiska w nowoczesnej nauce języków obcych uważane są za komponenty kulturowe, w badaniu też są uznawane za elementy wiedzy o świecie. Z tego wynika, że wiedza o świecie, którą definiuje się jako wiedzę na temat tego, jak świat funkcjonuje w danych kręgach kulturowych, w artykule jest szerzej zdefiniowana, obejmuje więc również niektóre odniesienia, które można nazwać uniwersalnymi. Niżej opisano kulturowo nacechowane elementy tekstów, a w tabeli znaleźć można wyniki dotyczące zdolności badanych, którzy w tekście rozpoznają nawiązania kulturowe i logicznie łączą je z treścią.

Rozumienie pierwszego tekstu wymagało wiedzy o niektórych odniesieniach do kultury ogólnej. Rozumienie pierwszego kulturowo nacechowanego elementu tekstowego zyskało rozpoznanie odniesień biblijnych („Niech się stanie światłość!” oraz „Bądźcie płodni i rozmnażajcie się”) ironizujących rolę fraz i (pustych) słów. Nutę ironii odczuwa się jeszcze bardziej przez połączenie aluzji biblijnych z kulturą popularną, dokładnie reklamą aktualną w ubiegłym wieku („Vacaciones sin Kodak son vacaciones perdidas”). Jeden z bohaterów porównywany jest także z Don Kichotem i Sinobrodym, co podkreśla, że był przebiegłym uwodzicielem.

Tabela 2. Tekst 1 - rozpoznanie referencji kulturowych

\begin{tabular}{|c|c|c|}
\hline & Procent poprawnych odpowiedzi & N \\
\hline referencja do Księgi Rodzaju & 63,4 & 26 \\
\hline $\begin{array}{c}\text { referencja do kultury popularnej i dyskursu } \\
\text { reklamowego }\end{array}$ & 26,8 & 11 \\
\hline referencja do Don Juana & 97 & 40 \\
\hline referencja do Sinobrodego & 9,8 & 4 \\
\hline
\end{tabular}

Źródło: oprac. własne

${ }^{5}$ Oprócz wymienionych inwentarzy, komponentem kulturalnym jest także inwentarz Habilidades y actitudes interculturales (Molina 2006). Każdy z inwentarzy posiada tematy i pojęcia, które mogą być relewantne w dydaktyce. 
W odróżnieniu od pierwszego i trzeciego fragmentu, do zrozumienia drugiego nie była potrzebna wiedza o kulturze ani wiedza o literaturze. Drugi tekst był dialogiem dwóch bezdomnych, z którego badani musieli zrozumieć: gdzie bohaterowie byli i spali, o czym rozmawiali i jak się tekst kończy. Miejscem akcji był hol banku z bankomatami. Rozumienie ostatniego akapitu fragmentu wymagało znajomości dziecięcej gry językowej veo veo, polegającej na odgadywaniu słowa po pierwszej literze.

Tabela 3. Tekst 2 - wiedza socjokulturowa potrzebna do rozumienia

\begin{tabular}{|c|c|c|}
\hline & $\begin{array}{c}\text { Procent poprawnych } \\
\text { odpowiedzi }\end{array}$ & N \\
\hline wnioskowanie o miejscu akcji & 9,8 & 4 \\
\hline $\begin{array}{c}\text { literatura oralna charakterystyczna dla } \\
\text { dyskursu dziecięcego }\end{array}$ & 12,2 & 5 \\
\hline
\end{tabular}

Źródło: oprac. własne

W trzecim fragmencie mówi się o tym, które książki powinno się zniszczyć, bo były powodem szaleństwa Don Kichota. Wymienione były Amadís de Gaula i La Diana. Badani musieli zrozumieć i wyjaśnić, czy te dzieła powinno się spalić czy nie.

Tabela 4. Tekst 3 - wnioskowanie oparte na szerszej wiedzy o treści powieści

\begin{tabular}{|c|c|c|}
\hline & $\begin{array}{c}\text { Procent poprawnych } \\
\text { odpowiedzi }\end{array}$ & N \\
\hline powody do zniszczenia książek rycerskich & 58,5 & 24 \\
\hline $\begin{array}{c}\text { Dlaczego należy oszczędzić książkę Amadísa } \\
\text { de Gaula? }\end{array}$ & 90,2 & 37 \\
\hline możliwy wpływ Diany na Don Kichota & 46,3 & 19 \\
\hline
\end{tabular}

Źródło: oprac. własne

Wyniki wskazują na to, że najwięcej trudności z czytaniem podtekstu kulturowego badani mieli z drugim fragmentem, mniej znane były także niektóre odniesienia w pierwszym fragmencie. Wysoki procent prawidłowych odpowiedzi po przeczytaniu trzeciego fragmentu potwierdza stosowanie wiedzy o powieści we wnioskowaniu i połączeniu informacji tekstowych.

\subsection{DYSKUSJA}

W ramach pytania badawczego interesowaliśmy się wpływem wiedzy kulturowej na rozumienie. Zaczynając od badań, z których wynika, że wiedza o kodzie językowym nie może zastąpić wiedzy o temacie, badaliśmy jakość rozumienia za pomocą czytania tekstów literackich w języku obcym. Przy tym interesowało nas 
rozumienie fragmentów, ale i rozumienie kulturowo nacechowanych elementów w tych fragmentach. Procent poprawnych odpowiedzi na pytania, którymi sprawdzano rozumienie tekstów, wskazuje na to, że najmniej trudności towarzyszyło rozumieniu pierwszego i trzeciego fragmentu. Czytanie pierwszego fragmentu, który badani zrozumieli najlepiej, wymagało zdekodowania czterech odniesień kulturowych. Chociaż z rozszyfrowaniem aluzji biblijnej i do Don Juana respondenci nie mieli większych trudności, zrozumienie nawiązania do hasła reklamowego aktualnego w drugiej połowie XX wieku, a także odniesienia do Sinobrodego, było kłopotliwe. Niezależnie od tego, napisali oni zadowalającą interpretację tekstu, co potwierdzają wyniki badania. Przy tym kształtowanie odpowiednej interpretacji można wyjaśnić rozpoznaniem aluzji kluczowej w tekście, czyli tej do Don Juana.

Na podstawie zebranych odpowiedzi można mówić także o zadowalającym rozumieniu trzeciego tekstu, fragmentu Don Kichota. Chociaż rozumienie tego tekstu nie jest uwarunkowane odniesieniami (tak jak pierwszy tekst), odpowiadający zyskali przynajmniej słabą wiedzę o treści. Ze względu na to, że to dzieło jest w Chorwacji częścią formalnej edukacji w szkołach średnich, a studenci hispanistyki spotykają się z nim kilkakrotnie podczas studiów, można było oczekiwać znajomości podstawowych elementów fabularnych, a potem także dobrego zrozumienia fragmentu, co potwierdziły wyniki. Rezultaty można połączyć z badaniem Winfield i Barnes-Felfeli, którzy właśnie na przykładzie Don Kichota udowodnili, że bliskość kulturowa wpływa pozytywnie nie tylko na rozumienie, lecz także i na pisanie w języku obycm. Może ona polepszać rozumienie zwłaszcza z poziomu wiedzy potrzebnej do odpowiednej integracji treści. Ze względu na to, że powieść Cervantesa i symbolika jej głównego bohatera dzisiaj, przynajmniej w kontekście europejskim, uważana jest za uniwersalną, stosunkowo dobre zrozumienie fragmentu można wyjaśnić opieraniem się badanych na schemacie treści.

Odpowiedzi wskazują też na to, że zrozumienie drugiego tekstu było najtrudniejsze. Pomimo iż trudność języka we wszystkich tekstach była wyrównana, jeżeli weźmiemy pod uwagę, że badani w drugim tekście oznaczyli mniej niż 2\% nieznanych słów i że potrzeba odniesienia do dotychczasowej wiedzy, przynajmniej w porównaniu z pozostałymi dwoma tekstami, była mniejsza, to takie wyniki nie są oczekiwane z kilku powodów. Po pierwsze, w tym tekście badani oznaczyli najmniej nieznanych wyrazów. Po drugie, w odróżnieniu od innych fragmentów, rozumienie tego nie wymagało wiedzy o literaturze (np. aluzja na Don Juana i Sinobrodego lub treść Don Kichota). Wiedza potrzebna do zrozumienia tego fragmentu dotyczyła funkcjonowania grup społecznych w miastach hiszpańskich oraz dziecięcej gry językowej veo veo. Jednak można je wyjaśnić niedostateczną wiedzą socjokulturową potrzebną do kształtowania interpretacji tekstu. Oprócz wykazania procentów poprawnych odpowiedzi, można to potwierdzić także wynikami z tabel. Okazało się, że nieco mniej niż jedna trzecia badanych 
napisała zadowalające streszczenie fragmentu. Ponownie przyczyną jest brak potrzebnej wiedzy kulturowej (nierozpoznanie veo veo). Ta ostatnia część drugiego fragmentu udowodnia również, że wiedza o strukturach gramatycznych i leksyce nie może zastąpić zrozumienia treści. Biorąc pod uwagę wszystkie wymienione czynniki, pierwszą hipotezę można uważać za potwierdzoną.

W ramach drugiej hipotezy interesowało nas jak czytelnicy, którzy nie posiadają potrzebnej wiedzy, rozumieją przeczytany tekst. Ze względu na to, że większość pytań była typu otwartego, niektóre odpowiedzi pokazały jak czytelnicy wyjaśnili kulturowo nacechowane elementy. Badania schematów wykazały, że rozumienie, jeżeli nie posiadamy odpowiedniej wiedzy, opieramy na wiedzy ogólnej - z tego też powodu możemy spodziewać się odchylenia w kształtowaniu interpretacji tekstu. W drugim tekście badani musieli wskazać miejsce akcji, dokładnie miejsce, gdzie śpią bezdomni. Chociaż w tekście są eksplicytnie napisane nazwy banków, $90,2 \%$ badanych $(\mathrm{N}=37)$ niepoprawnie odpowiedziało na to pytanie. Najczęściej opierali się na wiedzy ogólnej, więc wnioskowali, że śpią oni na ulicy, dworcu oraz w innych miejscach publicznych $(41,5 \%, \mathrm{~N}=17)$. Opieranie się na wiedzy ogólnej jest jeszcze bardziej oczywiste w odpowiedziach kilkorga badanych, w których polisemia dodatkowo utrudnia rozumienie (hisz. banco 'bank; ławka') - wnioskowali oni, że miejscem akcji jest ławka w miejscu publicznym. Błędy w rozumieniu oczywiste są $\mathrm{w}$ jeszcze innych odpowiedziach, jak na przykład w pytaniu o porównanie Sinobrodego z jednym z bohaterów. Ze względu na to, że na to pytanie poprawnie odpowiedziało tylko $9,8 \%$ badanych $(\mathrm{N}=4)$, niektóre odpowiedzi można również rozważać jako przykłady niepoprawnego wnioskowania uwarunkowanego opieraniem się na wiedzy ogólnej. Jako przykład, który to potwierdza, możemy wymienić interpretację brody jako symbolu męskości $(2,4 \%, \mathrm{~N}=1)$. Oprócz tego, niektórzy badani aluzję do Sinobrodego interpretują nadmierną troską o wygląd fizyczny $(7,3 \%, \mathrm{~N}=3)$. Możemy dojść do wniosku, że w rozumieniu tych elementów tekstowych, w których wymagane jest od czytelnika wnioskowanie oparte na wiedzy ogólnej, wśród czytelników, którzy nie posiadają odpowiedniej wiedzy, częściej pojawiają się bezzasadne interpretacje. Trudności we wnioskowaniu oczywiste są w interpretacji takich elementów tekstowych, za których rozumienie odpowiedzialna jest wiedza kulturowa. W tym sensie i drugą hipotezę można uważać za potwierdzoną.

\section{PODSUMOWANIE}

Celem opisanego $\mathrm{w}$ arytkule badania było przeanalizowanie rozumienia w czytaniu tekstów literackich w języku hiszpańskim jako obcym. Zaczynając od niektórych nowych podziałów, uważających czytanie w języku obcym za mię- 
dzykulturowe czytanie, chcieliśmy przebadać, jak czytelnicy kształtują obraz tekstów literackich napisanych na poziomie językowym odpowiednim dla nich, gdy do zrozumienia jest również potrzebna wiedza kulturowa. Wyniki są zgodne z poprzednimi badaniami, które zwróciły uwagę na fakt, że wiedza o kodzie językowym nie może w pełni zastąpić wiedzy o treści tekstu oraz że rozumienie zależy także od wiedzy o świecie. Wnioski można wykorzystać w nauczaniu języków obcych, ponieważ, po pierwsze - podkreślają znaczenie wiedzy o świecie w rozumieniu tekstów literackich i rozumieniu w ogóle, a po drugie - umożliwiają rozpoznanie kulturowo nacechowanych elementów tekstowych jako elementów trudniejszych w zrozumieniu. To umożliwia lepsze planowanie nauki i może przyczynić się do większej satysfakcji uczących się z obcowania z tekstem.

\section{BIBLIOGRAFIA}

Alderson C., 2000, Assesing Reading, Cambridge.

Al-Issa A., 2006, Schema Theory and L2 Reading Comprehension, „Journal of College Teaching and Learning", nr 7, s. 41-47.

Anderson R. C., 2004, Role of the Reader's Schema in Comprehension, Learning and Memory, w: R. B. Ruddel, N. J. Unrau (red.), Theoretical Models and Processes of Reading, Newark, s. 594-606.

Bartlett F., 1932, Remembering: a study in experimental and social psychology, London.

Carell L. Patricia, 1983, Some Issues in Studying the Role of Schemata, or Background Knowledge in Second Language Comprehension, „The Reading Procces”, nr 2, s.81-92.

Carrell P., Eisterhold, J., 1983, Schema theory and ESL Reading Pedagogy, „TESOL Quarterly”, nr 4. [online] http://nflrc.hawaii.edu/Rfl/PastIssues/rfl12carrell.pdf, [13.5.2011].

Čudina-Obradović M., 2014, Psihologija čitanja: od motivacije do razumijevanja, Zagreb.

Davoudi M., Ramezani, H., 2014, The Effects of Cultural Familiarity on Reading Comprehension of Iranian EFL Learners, „IJSELL” nr 8, s. 58-71.

Grabe W., Stoller F., 2002, Teaching and Researching Reading, New York.

Grabe W., 2009, Reading in Second Language. Moving from Theory to Practice, Cambridge.

Grosman M., 2004, Književnost v medkulturnem položaju, Ljubljana.

Kintsch W., 2004, The Construction-Integration Model of Text Comprehension and Its Implications for Instruction, w: R. B. Ruddel, N. J. Unrau (red.), Theoretical Models and Processes of Reading, Newark, s. 1270-1328.

Koda K., 2010, The role of reading in fostering transcultural competence, „Reading in a Foreign Language" nr 1, s. 5-10.

López Alonso C., Sérrè A., 2001, Lectura en lengua extranjera. El caso de las lenguas románicas, Hamburg.

Nagy W., Scott J., 2004, Vocabulary Processes, w: R. B. Ruddel, N. J. Unrau (red.), Theoretical Models and Processes of Reading, Newark, s. 574-593.

Perfetti, C. i in. 2009, The Acquisition of Reading Comprehension Skill. The Science of Reading: A Handbook, w: M. Snowling, C. Hulme (red.), Oxford, s. 227-253.

Molina C. (red.), 2006, Plan Curricular del Instituto Cervantes, Niveles de referencia para el español: B1, B2, Madrid. 
Van Dijk T., Kintsch W., 1983, Strategies of Discourse Comprehension, New York.

Waring R., Nation P., 1997, Vocabulary size, text coverage, and word lists, w: N. Schmitt, M. McCarthy (red.), Vocabulary: Description, Acquisition and Pedagogy, Cambridge, s. 6-19. Vijeće Europe, 2005., Zajednički europski referentni okvir za jezike, Zagreb.

Ana Ćavar

\section{THE KNOWLEGE OF THE WORLD AND READING COMPREHENSION IN SPANISH AS A FOREIGN LANGUAGE}

Keywords: reading in a foreign language, understanding literary texts, the knowledge of the world, Spanish as a foreign language

Summary. The aim of the article is to give insight into reading comprehension and the role of prior knowledge in reading literary texts in Spanish as a foreign language. In order to achieve this, the author conducted a survey to investigate understanding and inferencing in understanding of the culturally marked text elements in three literary texts fragments. The subjects were students of the first and the second year of Spanish language and literature. The results indicate that it requires both linguistic and cultural knowledge to establish adequate comprehension and that the knowledge of the language cannot compensate for insufficient knowledge of the world. 